\title{
Transmisi Suara dan Pengendalian Penyuara melalui Jala-Jala berbasis IC LM1893
}

\author{
Budihardja Murtianta ${ }^{1}$, Hendry Yuwono Ariowibowo ${ }^{2}$, F.D. Setiaji ${ }^{3}$ \\ Program Studi Teknik Elektro, \\ Fakultas Teknik Elektronika dan Komputer, \\ Universitas Kristen Satya Wacana, Salatiga \\ 1budihardja.murtianta@staff.uksw.edu, 2hendry_nitr0zz@yahoo.com,ffdsetiaji@gmail.com
}

\begin{abstract}
Ringkasan
LM 1893 (Carrier Current Transceiver) adalah IC (Integrated Circuit) yang dapat digunakan untuk komunikasi melalui jala-jala listrik atau PLC (Power Line Communication). Pada umumnya LM 1893 dipergunakan untuk mengirimkan data digital yang akan dimodulasi (di bagian pengirim) secara FSK (Frequency Shift Keying) oleh IC tersebut sebelum ditumpangkan ke tegangan sinusoidal jala-jala. Di bagian penerima, LM 1893 akan mendemodulasinya menjadi data digital kembali. Namun demikian, IC tersebut sebetulnya juga memiliki kemampuan untuk mengirimkan data analog yaitu wicara (voice) melalui modulasi dan demodulasi FM (Frequency Modulation). Makalah ini menggabungkan kedua kemampuan tersebut untuk mengirimkan suara melalui jala-jala secara selektif ke salah satu dari beberapa penyuara yang terhubung ke sistem. Setiap penyuara diberi alamat tertentu sehingga sistem dapat mengendalikan penyuara mana yang akan menyuarakan data suara yang dikirim. Hasil pengujian menunjukkan bahwa alat yang dibuat mampu mengirimkan data suara ke penyuara yang dipilih. Namun demikian kualitas suara yang sampai ke penerima masih kurang bagus antara lain akibat adanya derau pada tegangan jala-jala.
\end{abstract}

Kata kunci:LM 1893, FSK,FM, Suara, master, slave,

\section{Pendahuluan}

PLC merupakan teknologi komunikasi yang mempergunakan jaringan listrik sebagai media pembawa informasi. Sistem ini berguna untuk melayani kebutuhan komunikasi khususnya pada daerah-daerah pedalaman yang sulit dijangkau. Keuntungan dari sistem komunikasi ini adalah nilai investasi yang cukup ekonomis karena memanfaatkan jaringan listrik milik PLN yang sudah ada [1]. Dengan teknologi transmisi data yang mutakhir akan membuat PLC dapat mentransmisikan data berkecepatan tinggi dengan biaya relatif murah [2].

Salah satu IC yang mendukung aplikasi PLC adalah LM 1893 yang memiliki kemampuan mengirimkan dan menerima (sebagai modem) data digital[3]. Pemanfaatan IC tersebut sebagai modem digital sudah banyak dibuat untuk sejumlah aplikasi. [4],[5],[6].

Selain itu, LM 1893 juga memiliki kemampuan untuk menerima data suara. Oleh sebab itu pada makalah ini dibuat suatu alat yang menggabungkan kedua kemampuan tersebut. Yaitu mempergunakan jala-jala sebagai media untuk menyalurkan informasi suara ke penyuara tertentu dari sejumlah penyuara yang tersedia. Sistem yang dibuat ini dapat digunakan di lingkungan sekolah, di mana seringkali dibutuhkan untuk 
memberikan pengumuman melalui penyuara ke suatu ruang kelas tertentu yang saja. Sedangkan ruang kelas yang tidak berkepentingan tidak perlu mendengarkan pengumuman tersebut. Jadi walaupun di setiap ruang kelas ada penyuara, namun masing-masing penyuara hanya berbunyi secara selektif. Dalam hal ini alat yang mengatur pengiriman suara bertindak sebagai Master, sedangkan masing-masing penyuara berfungsi sebagai Slave.

\section{Dasar Teori}

\subsection{Power Line Carrier (PLC)}

Pada komunikasi PLC, jala-jala selain berfungsi menghantarkan tenaga listrik juga digunakan untuk membawa informasi atau data. Pada dasarnya sinyal informasi tersebut ditumpangkan ke jaringan listrik PLN 220V/50Hz yang sudah tersedia, melalui proses modulasi pada bagian pengirim (transmitter). Kemudian dibagian penerima (receiver) sinyal sinyal termodulasi kemudian didemodulasi supaya menjadi sinyal informasi semula.

\subsection{Modulasi Binary Frequency Shift Keying (BFSK)}

Binary Frequency Shift Keying (BFSK) adalah sebuah metode modulasi data digital, sesuai dengan namanya metode modulasi ini mengubah nilai frekuensi carrier untuk merepresentasikan data digital berdasarkan pada kondisi data. Dalam transmisi data digital ada dua macam kondisi yaitu ' 1 ' dan ' 0 ' atau high dan low. Berdasar kondisi tersebut data akan dimodulasi secara BFSK, sinyal carrier atau sinyal pembawa akan dibuat bervariasi untuk merepresentasikan data. Sinyal pembawa yang dibentuk berupa gelombang sinus. Frekuensi sinyal pembawa dibagi menjadi dua yaitu $f_{1}$ dan $f_{2}$. Frekuensi sinyal pembawa $f_{1}$ digunakan untuk merepresentasi data yang bernilai ' 0 ' dan frekuensi $f_{2}$ digunakan untuk merepresentasikan data yang bernilai ' 1 '.

\subsection{Transformator dan Kapasitor Coupling}

Transformator atau trafo dapat berfungsi sebagai jembatan bagi sinyal termodulasi untuk ditumpangkan ke jala-jala listrik PLN. Kapasitor coupling berfungsi untuk memblok sinyal Direct Current (DC) dan melewatkan sinyal AC. Namun kapasitor coupling juga bisa bertindak sebagai high-pass filter, yang berarti akan melemahkan sinyal di bawah titik frekuensi tertentu. Jadi kapasitor coupling dapat digunakan untuk mengisolasi jala-jala listrik PLN dari rangkaian modem.

\subsection{IC LM1893}

LM1893 adalah IC yang dikembangkan oleh National Semiconductor dimana konfigurasinya ditunjukkan pada Gambar 1 dan fungsi utamanya sebagai modulator atau demodulator data digital dan sebagai antarmuka komunikasi melalui jala-jala listrik. Beberapa fasilitas yang dimiliki oleh IC ini adalah sebagai berikut:

a. Modulasi atau demodulasi BFSK.

b. Sinyal pembawa dapat divariasikan antara $50 \mathrm{kHz}$ hingga $300 \mathrm{kHz}$.

c. Dapat dikondisikan sebagai pengirim $(t x)$ atau penerima $(r x)$.

d. Mendukung komunikasi dua arah (half duplex).

e. Kecepatan pengiriman data hingga 4.800 bps.

f. Dapat digunakan pada level tegangan TTL maupun MOS. 


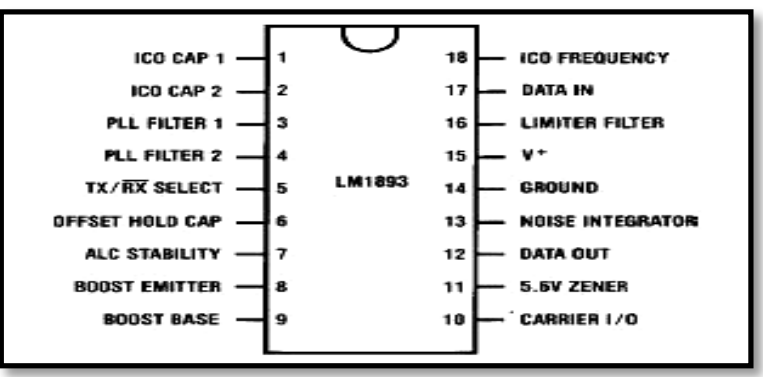

Gambar 1. Konfigurasi pin IC LM1893 [3]

Gambar 2 menunjukkan rangkaian modem PLC yang dibangun dengan komponen utama IC LM1893 dengan beberapa komponen tambahan yang akan menghasilkan sinyal pembawa (carrier) sebesar $125 \mathrm{kHz}$.

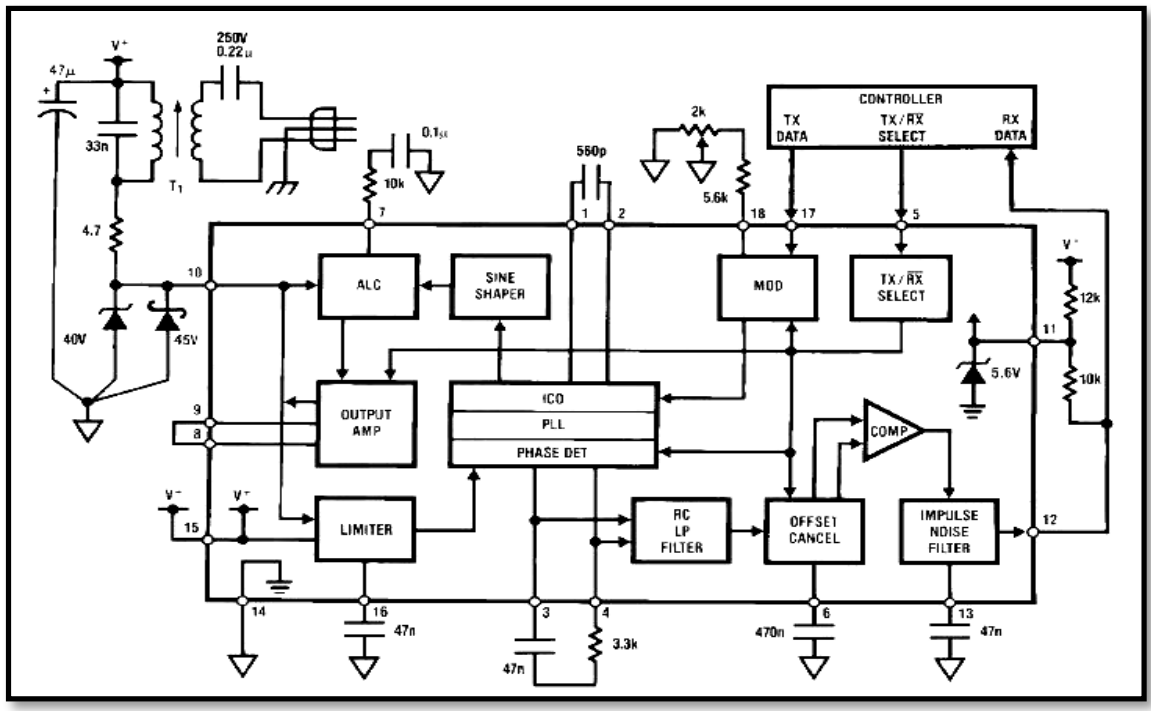

Gambar 2. Rangkaian modem PLC [5]

\section{PerancanganSistem}

Sistem kendali speaker melalui jala-jala listrik PLN ini terdiri dari dua bagian pokok, yaitu master dan slave. Bagian master merupakan bagian transmitter di mana informasi dikirimkan dan bagian slave (receiver) yang akan menerima informasi itu. Kedua bagian itu terhubung melalui jala-jala listrik PLN dengan diagram blok ditunjukkan Gambar 3.

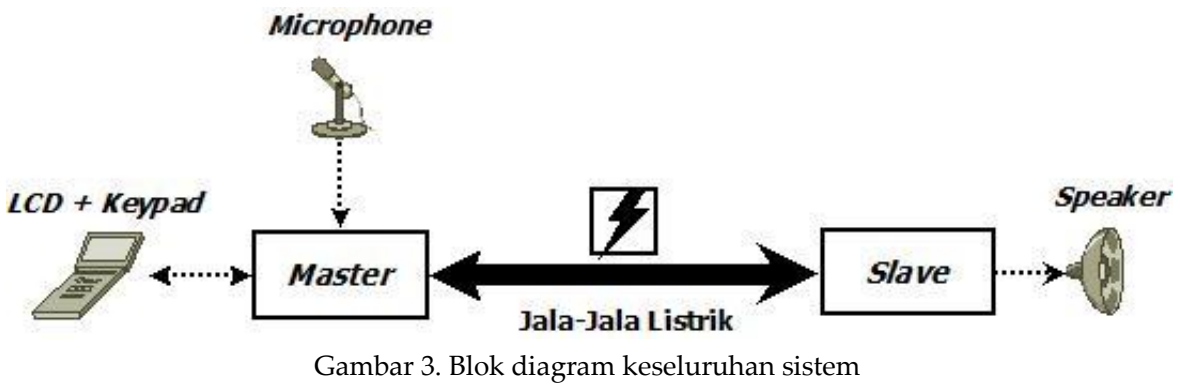


Modul masteryang dibuat dapat mengontrol maksimal 16 modul slave yang masingmasing diberi alamat 4 bit melalui pengaturan dip switch. Komunikasi antara modul master dan modul slave akan diatur melalui protokol tertentu.

\section{1. $\quad$ Modul Master}

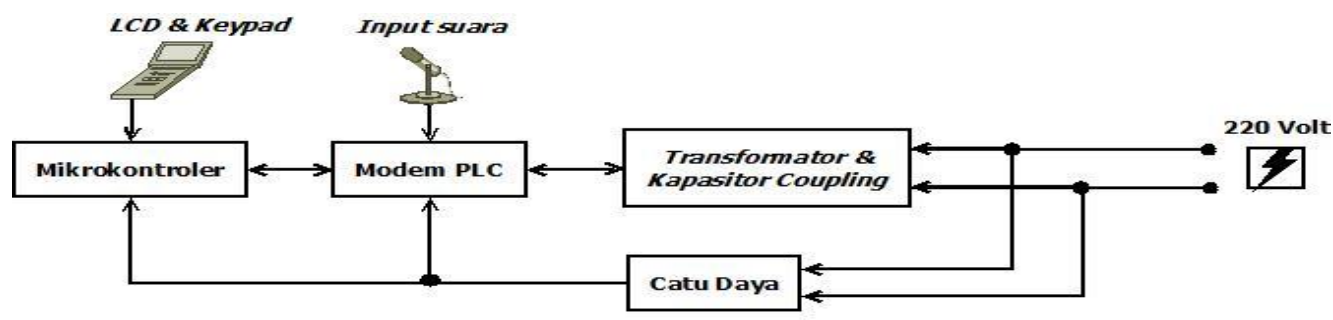

Gambar 4. Blok diagram modul master

Gambar 4 menunjukkan blok diagram modul master. Mikrokontroler berfungsi sebagai penerima masukan dari pengguna melalui keypad danmenampilkannya pada LCD, mengatur mode kerja modem PLC, serta menyediakan komunikasi serial USART sebagai metode komunikasi antara master dan slave.Mikrokontroler yang dipakai adalah ATmega8535 dengan catu $5 \mathrm{~V}$.

Tabel 1. Konfigurasi pin ATmega8535 pada master
\begin{tabular}{|c|c|}
\hline PORT & Koneksi/Fungsi \\
\hline \hline PORTA & Scanning Keypad \\
\hline PORTB.5 & MOSI (downloader $)$ \\
\hline PORTB.6 & MISO (downloader $)$ \\
\hline PORTB.7 & SCK (downloader) \\
\hline PORTC & LCD \\
\hline PORTD.0 & to RX Modem \\
\hline PORTD.1 & to TX Modem \\
\hline PORTD. 2 & to Selector TX/RX Modem \\
\hline
\end{tabular}

Modem PLC yang merupakan komponen utama dalam blok diagram tersebut dapat berkomunikasi dua arah (half-duplex). Modem PLC ini menggunakan IC LM1893 yang perancangannya menggunakan rangkaian yang ada di datasheet IC tersebut.[3]

Dalam perancangan ini rangkaian modem PLC memiliki tiga pin antarmuka dengan mikrokontroler yaitu TX (pin 17), RX (pin 12), dan selector (pin 5). TX modem dihubungkan dengan PD.1 (TXD) pada mikrokontroler, RX modem dihubungkan dengan PD.0 (RXD) pada mikrokontroler dan selector dihubungkan ke PD.2 pada mikrokontroler. Fungsi selector pada modem PLC adalah sebagai pemilih mode modem, kerja modem sebagai pengirim atau sebagai penerima. Ketika selector pada modem bernilai high maka modem dikondisikan sebagai pengirim, pada saat modem bekerja sebagai pengirim maka input data serial yang terhubung pada pin $\mathrm{TX}$ akan dimodulasi secara BFSK. Hasil modulasi yang dilakukan oleh modem berupa gelombang sinus dengan frekuensi $\pm 127,75 \mathrm{kHz}$ untuk merepresentasikan data ' 0 ' dan $\pm 122,25 \mathrm{kHz}$ untuk merepresentasikan data ' 1 ' dengan amplitudo sebesar \pm 4 VPP. Data hasil modulasi kemudian ditumpangkan ke jala-jala listrik oleh modem melalui trafo $\mathrm{T}_{1}$, trafo $\mathrm{T}_{1}$ ini berfungsi sebagai trafo coupling.Sebaliknya ketika selector pada modem bernilai low maka modem dikondisikan sebagai penerima. Kerja modem saat sebagai penerima adalah kebalikan ketika modem sebagai pengirim. Jika ada data yang masuk maka data akan 
didemodulasi oleh modem sehingga data dapat dikenali oleh mikrokontroler. Data hasil demodulasi disalurkan pada pin RX yang dihubungkan ke pin RXD pada mikrokontroler.

Gambar 5 menunjukkan skema rangkaian modem PLC yang dirancang berdasarkan skema rangkaian yang terdapat pada datasheet IC LM1893.Masukansuara yang akan dimodulasi frekuensi (FM) oleh LM1893 dengan sinyal carrier $125 \mathrm{kHz}$ diberikan pin 18 melalui sebuah kapasitor $10 \mathrm{nF}$ diseri dengan resistor $390 \mathrm{k} \Omega$. Aras sinyal masukan yang direkomendasikan adalah sekitar sekitar 1 Vpp.[3]

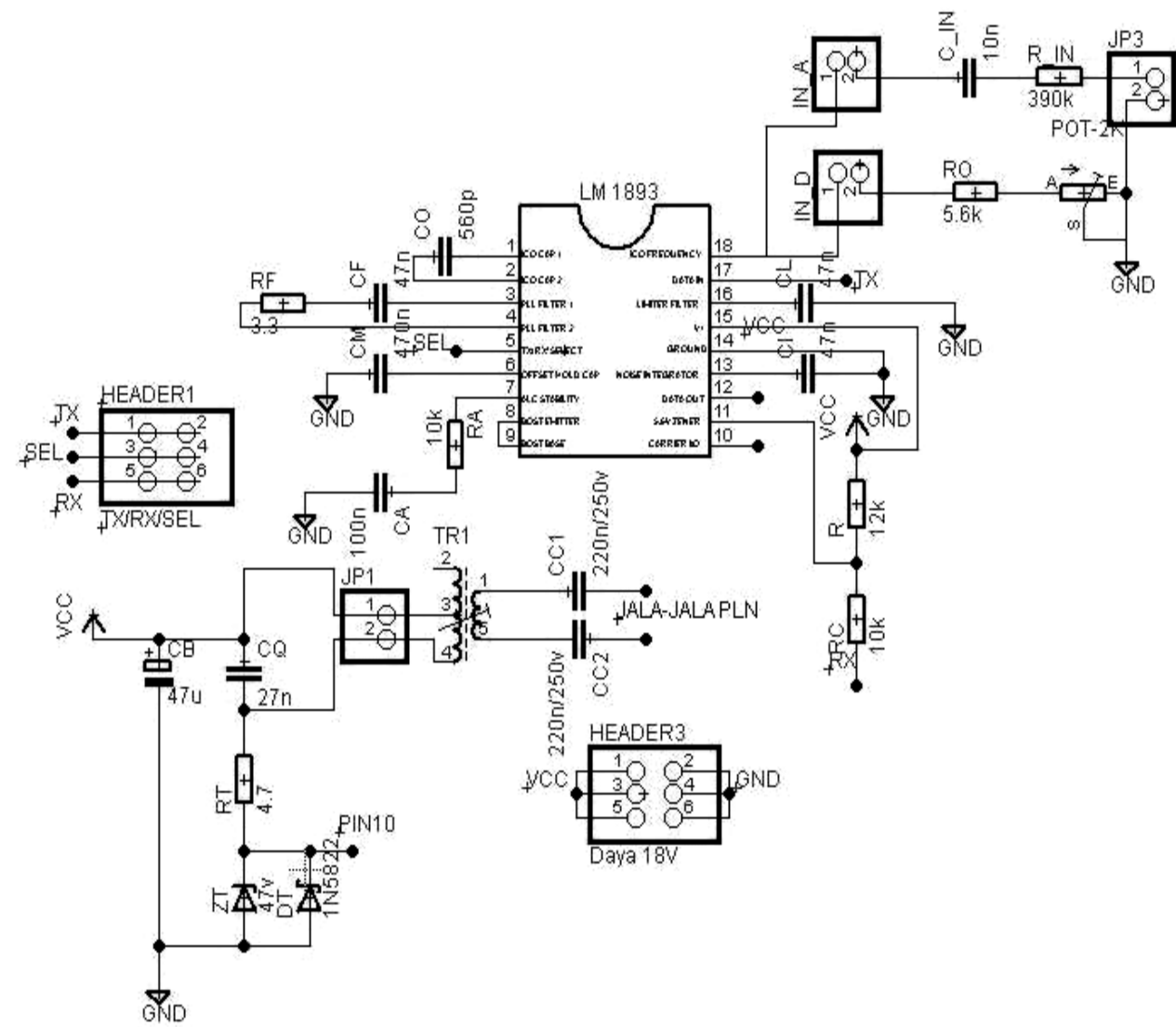

Gambar 5. Skematik modul modem PLC master

\subsection{Modul Slave}

Blok diagramGambar 6 menunjukkan modul slaveyang mencakup mikrokontroler, modul modem PLC (LM 1893) untuk transmisi digital, trafo IF dan kapasitor coupling, catu daya, dan part tambahan modul modem PLC (LM 1893) untuk transmisi audio, yaitu filter dan amplifier audio eksternal, carrier detector, dan relay. 


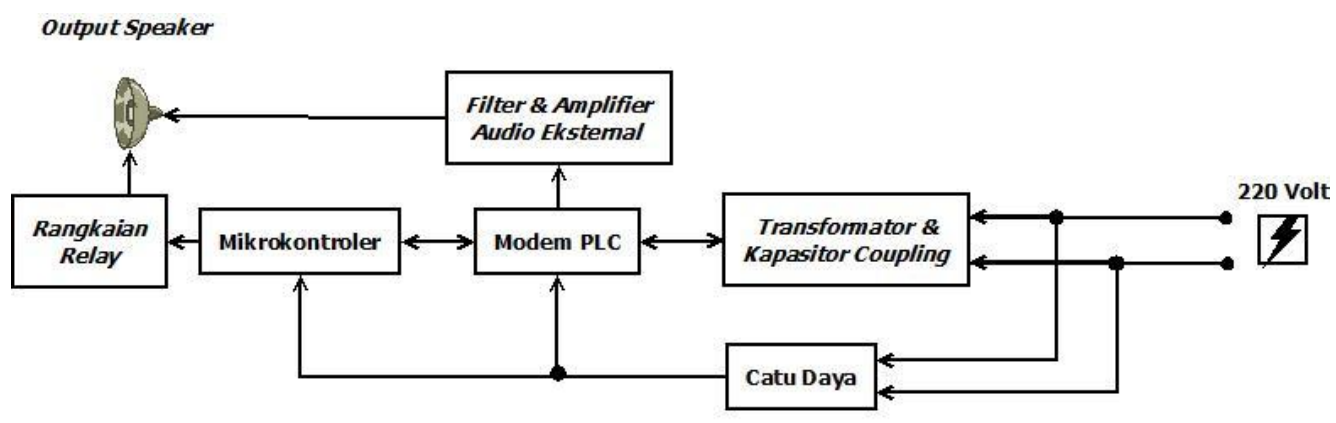

Gambar 6. Blok diagram modul slave

Mikrokontroler pada bagian slave berfungsi sebagai pengatur jalannya komunikasi antara master dan slave melalui USART dan sebagai pengatur mode kerja dari modem PLC. Mikrokontroler juga akan mengendalikan aktif atau tidaknya penyuara (speaker). Setiap Slave juga memiliki alamat yang dapat diatur melalui dip-switch 4 pin. Konfigurasi pin mikrokontroler slave adalah sebagai berikut:

Tabel 2. Konfigurasi pin ATmega8535 pada slave

\begin{tabular}{|c|c|}
\hline PORT & Kegunaan \\
\hline \hline PORTB.5 & MOSI (downloader) \\
\hline PORTB.6 & MISO (downloader) \\
\hline PORTB.7 & SCK (downloader) \\
\hline PORTC.0 & Kontrol speaker \\
\hline PORTC.1 & Kontrol jalur audio filter PLL \\
\hline PORTC.2 & Input carrier detector \\
\hline PORTD.0 & to RX Modem \\
\hline PORTD.1 & to TX Modem \\
\hline PORTD. 2 & to Selector TX/RX Modem \\
\hline PORTD.3-6 & dip-switch 4 pin (addressing) \\
\hline
\end{tabular}

Perancangan modem PLC pada modul slave sama dengan perancangan modem PLC pada modul master. Namun karena modul slave juga akan menerima data suara selain data digital untuk mengontrol penyuara yang terhubung dengannya, maka pada LM1893 modem slave, pin 3 dan 4 dihubungkan ke sebuah relay yang akan mengatur mode penerimaan modem slave sebagai penerima data digital atau data analog (suara). Jika mode yang dipilih adalah mode penerima data digital maka rangkaian modem slave pada pin 3 dan 4 akan terhubung $\mathrm{ke}_{\mathrm{F}}$ dan $\mathrm{R}_{\mathrm{F}}$ seperti pada rangkaian modem master.

Sedangkan bila yang dipilih adalah mode penerima data analog, dengan memberi relay logika " 1 " dari mikrokontroler maka relay akan menghubungkan pin 3 dan 4 ke filter dan audio amplifier eksternal yang dibuat berdasarkan [3]. Gambar 7 menunjukkan skema rangkaian modem PLC slave yang direalisasikan. 


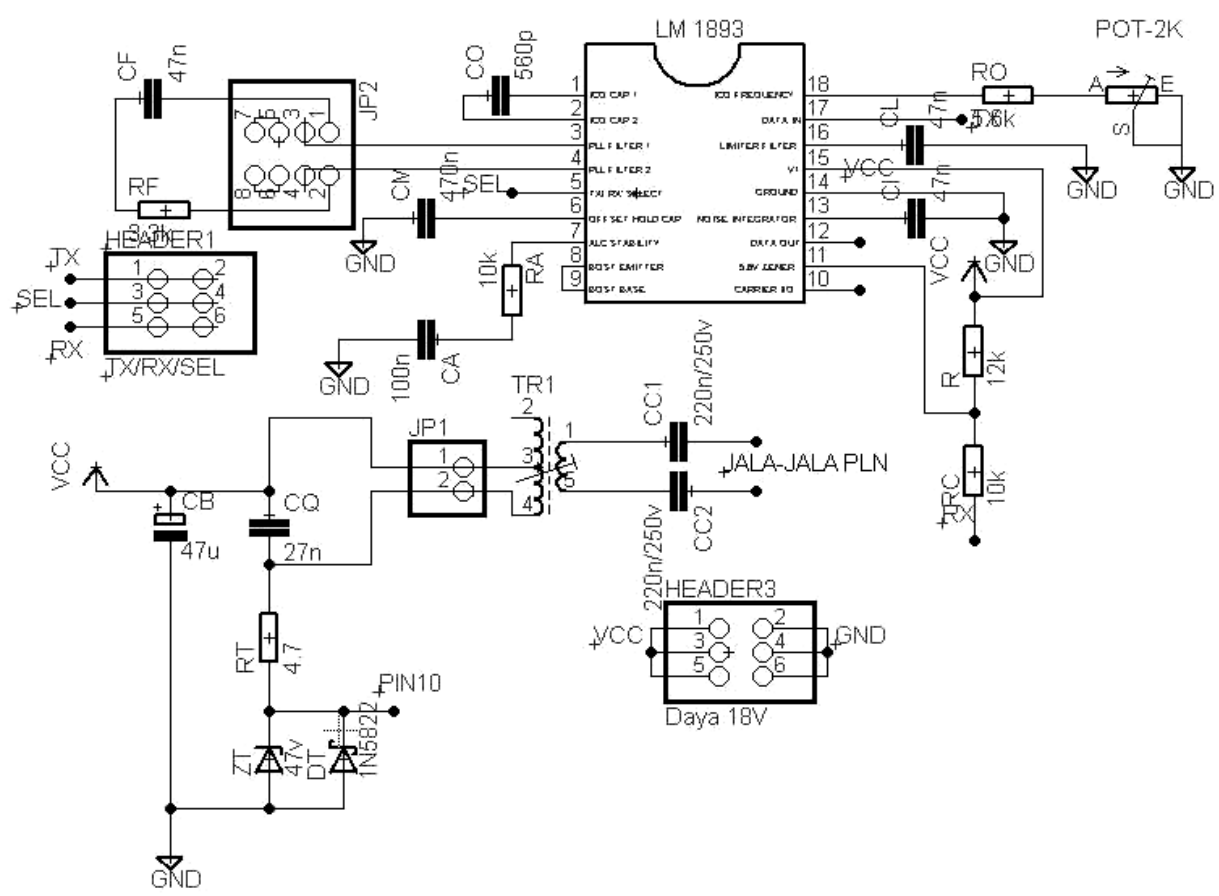

Gambar 7. Skematik modul modem PLC slave

\subsection{Diagram Alir Perangkat Lunak Sistem}

Gambar 8 menunjukkan diagram alir software utama master yang memiliki user interface berupa LCD dan scanning keypad. Berikut penjelasan ringkas tentang diagram alir program utama master: Pada menu utama pada LCD, ada tiga pilihan menu: cek speaker, atur speaker, dan mulai bicara.

Menu cek speaker adalah untuk mengecek kondisi semua speaker pada slave, apakah on/off. Saat master selesai mengecek semua speaker, hasilnya akan ditampilkan pada layar LCD.Menu atur speaker akan mengganti layar LCD ke pilihan berikutnya yang harus diinputuser menggunakan scanning keypad. Inputan yang harus dimasukkan user berupa nama kelas yang akan diatur speakernya, atau dapat juga memasukkan karakter "\#A" yang merupakan pilihan untuk mengatur semua kelas.

Bila yang dipilih user adalah mengatur speaker di slave tertentu, akan ada pilihan untuk mengecek speaker dan meng-on/off-kan speaker pada sebuah slave tertentu saja. Perintah on/offspeaker ke sebuah slave tertentu akan dikirimkan ke slave dengan alamat tertentu. Perintah ini membutuhkan konfirmasi balik untuk mengetahui apakah perintah sampai dan dilaksanakan oleh slave. 


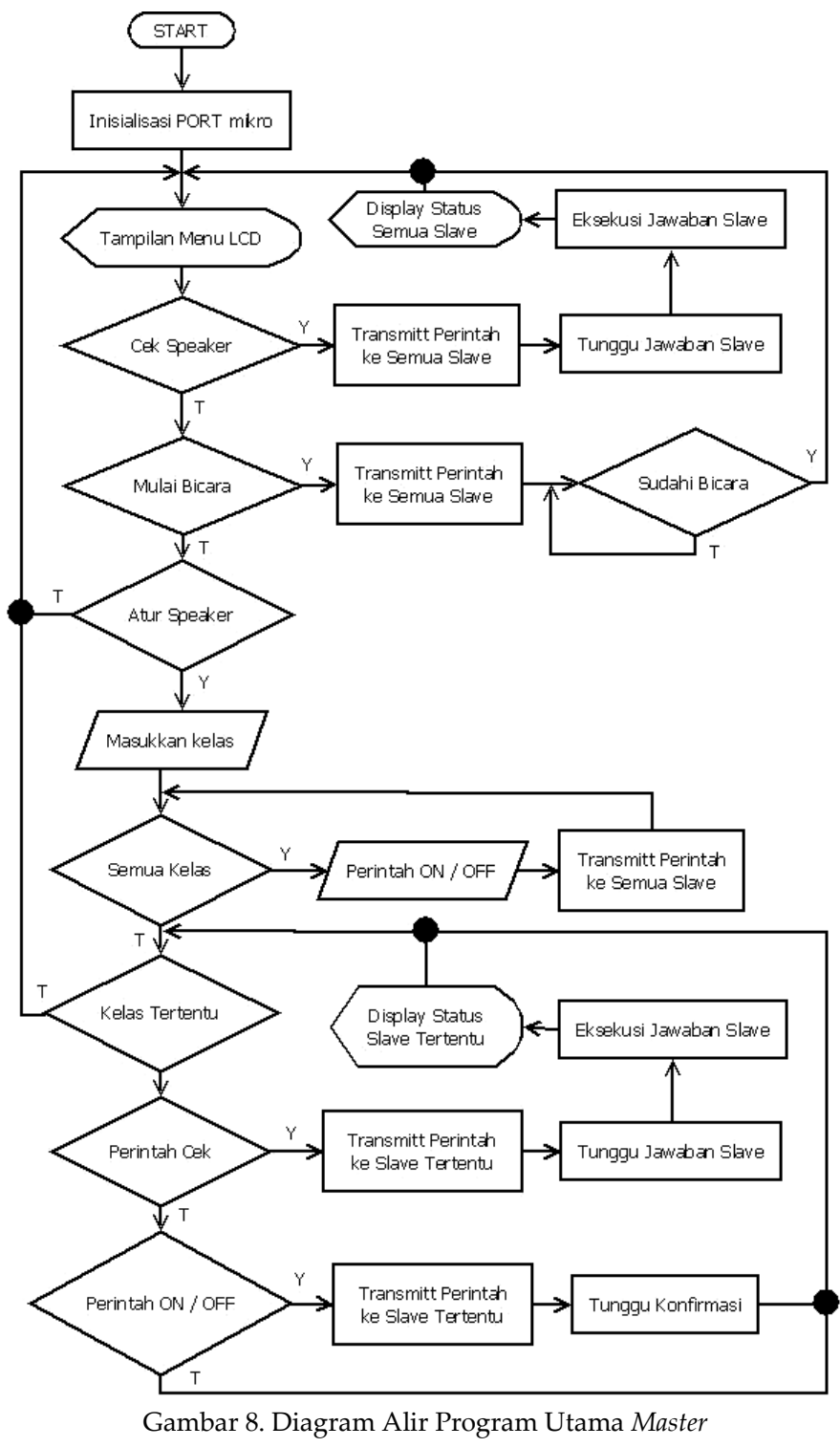

Menu terakhir dari software master adalah menu untuk memulai bicara ke speaker pada tiap slave yang aktif dan speaker-nya dalam kondisi on. Master akan mengirimkan perintah untuk memindah jalur informasi slave menjadi analog sebanyak tiga kali, lalu user dapat memulai bicara pada mic. Kondisi jalur penerima slave akan menjadi digital kembali 5 detik setelah user keluar dari menu mulai bicara.

Gambar 9 menunjukkan diagram alir software utama slave yang memiliki output berupa kontrol speaker, kontrol jalur data, dan speaker. Berikut adalah penjelasan dari diagram alir program utama slave:

Softwareslave ini akan menunggu sampai ada masukan data serial dari master. Jika ada masukan data serial dari master, software akan menyimpan data-data yang masuk ke sebuah variabel sebagai penyimpanan sementara. Data-data yang masuk kemudian dicek apakah data yang masuk merupakan perintah dari master ke slave. Perintah dibagi dua, yaitu yang memerlukan timbal balik dan tanpa timbal balik ke master. Perintah tanpa timbal balik misalnya adalah mulai bicara. Jika perintah mulai bicara yang terdeteksi, 
maka dilihat apakah kondisi speaker slave aktif. Bila aktif maka slave mengubah jalur data digital menjadi analog agar penyuara bisa menyuarakan suara dari master.

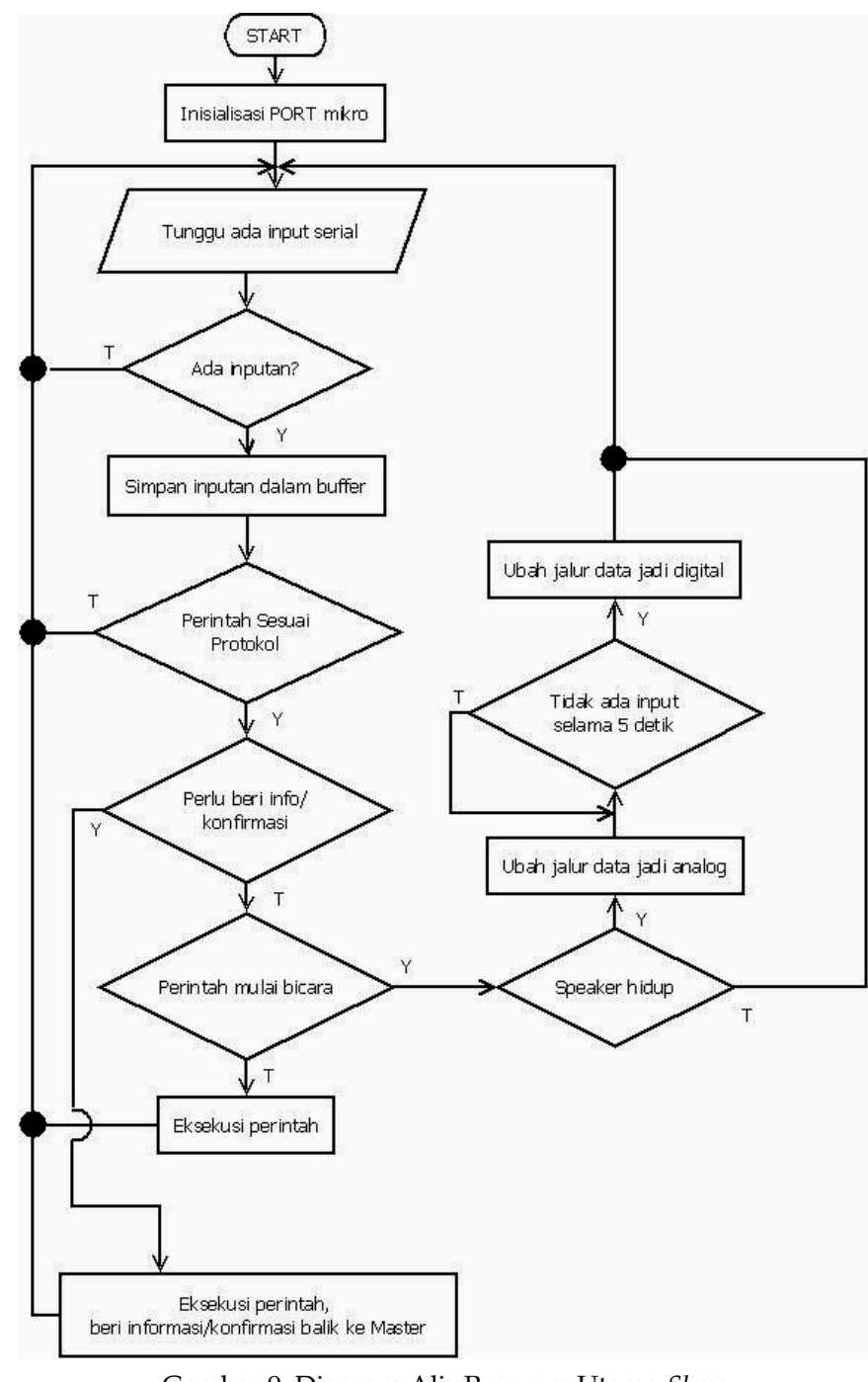

Gambar 9. Diagram Alir Program Utama Slave

Jika masukannya membutuhkan timbal balik berupa informasi kondisi speaker maupun hanya konfirmasi, perintah akan langsung dieksekusi kemudian slave mengirimkan informasi/konfirmasi sesuai permintaan master.

\section{Pengujian Sistem}

\subsection{Pengujian Modem PLC Untuk Transmisi Data Analog}

Untuk pengujian modem sebagai transmisi data analog (suara) akan melibatkan modem transmitter dan receiver. Modem transmitterdikondisikan sebagai berikut ini: mode transmit (pin 5 high), sinyal carrier berada pada $\pm 122,25 \mathrm{kHz}$ (pin 17 high), dan sinyal input analog pada pin 18 sekitar $1 \mathrm{Vpp}$. Modem receiverdikondisikan mode receiver (pin 5 low) dan jalur data dialihkan ke jalur data analog (relay pada normally closed). Dalam pengujian akan dilakukan dengan input sinyal dari function generator (FG) dengan 
frekuensi $300 \mathrm{~Hz}-10 \mathrm{kHz}$ dengan amplitude $1 \mathrm{Vpp}$. Salah satu pengukuran yang dilakukan adalah pada pin 10 modem master.

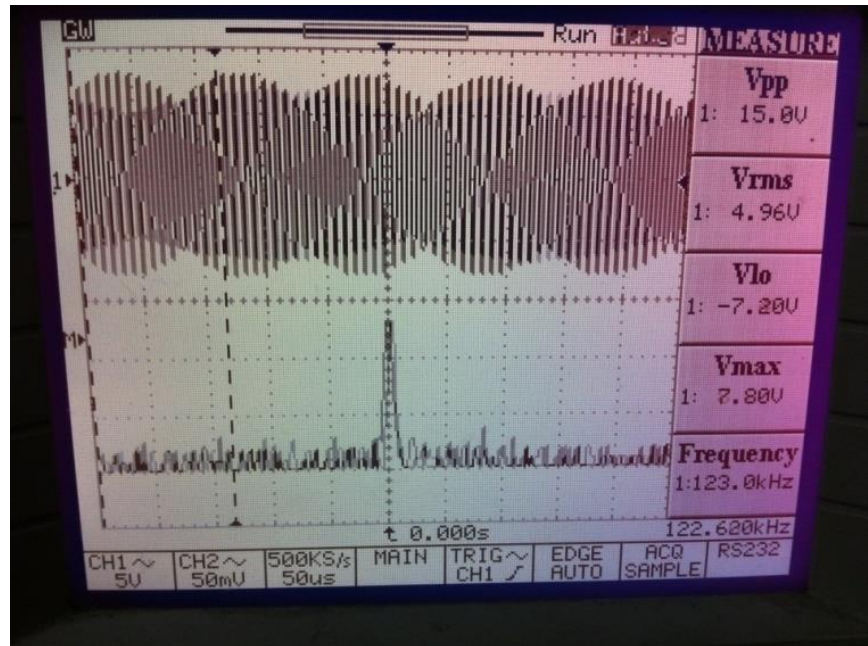

Gambar 10. Hasil pengukuran pada transmitter tanpa input data analog

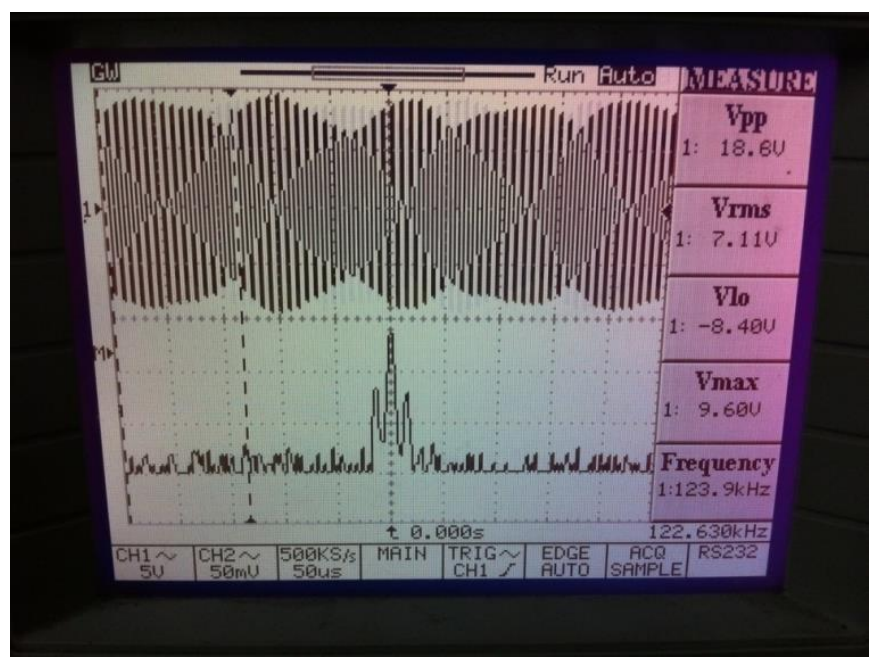

Gambar 11. Hasil pengukuran pada transmitter dengan input data analog $7 \mathrm{kHz}$

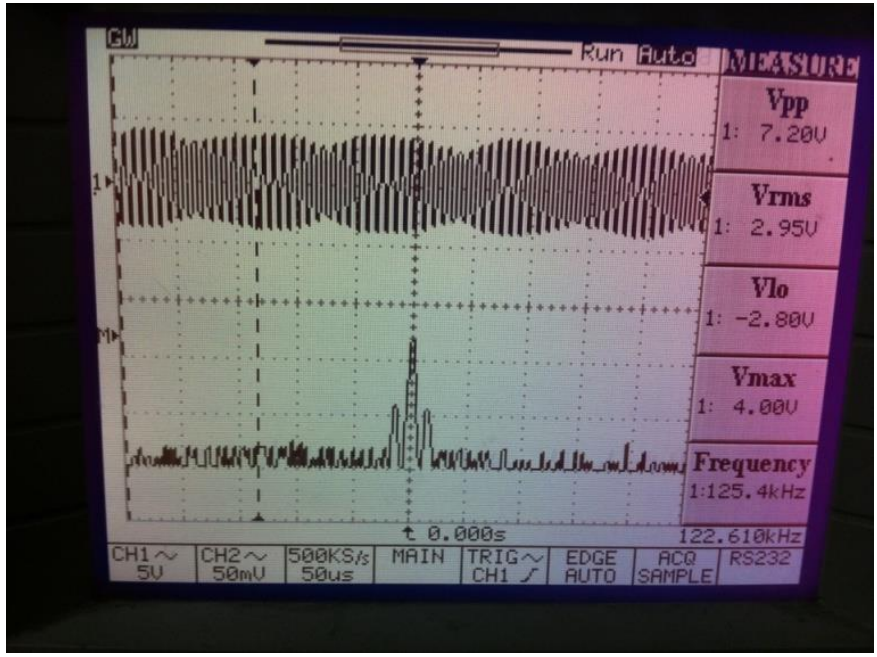

Gambar 12. Hasil pengukuran pada receiver dengan input data analog $7 \mathrm{kHz}$ 
Gambar 10, 11, dan 12 menunjukan hasil pengukuran pada modem transmitter dan receiver pada pengujian transmisi data analog dengan jala-jala. Dari hasil pengujian tampak bahwa adanya derau yang mempengaruhi sinyal yang dikirimkan oleh transmitter ke receiver.Namun sinyal yang dikirim dari transmitter dapat sampai dengan cukup baik direceiver, terlihat darihasil pengukuran di pin 10 receiver yang relatifsama dengan hasil pengukuran di pin 10 transmitter.

Untuk mengetahui apakah sinyal termodulasi pada pin 10 modem dapat didemodulasi dengan baik, dilakukan pengujian dengan menggunakan osiloskop pada filter dan audio amplifier eksternal. Modem transmitter akan mengirimkan sinyal dari function generatordari rentang $300-13 \mathrm{kHz}$, kemudian akan dilihat apakah keluaran dari filter dan audio amplifier eksternal pada receiver memperlihatkan sinyal keluaran yang sama dengan input pada transmitter, seperti disimpulkan pada Tabel 4.3.

Tabel 3. Hasil pengujian output jalur data analog pada receiver pada jala-jala

\begin{tabular}{|c|c|c|c|}
\hline $\begin{array}{l}\text { Frekuensi input pada } \\
\text { transmitter }(\mathrm{kHz})\end{array}$ & Amplitudeinput(Vpp) & $\begin{array}{c}\text { Frekuensi output } \\
\text { pada receiver }(\mathrm{kHz})\end{array}$ & Amplitudeoutput(mVpp) \\
\hline $\pm 0,3$ & 1 & $\pm 0,3$ & \pm 920 \\
\hline \pm 1 & 1 & \pm 1 & \pm 904 \\
\hline \pm 2 & 1 & \pm 2 & \pm 808 \\
\hline \pm 3 & 1 & \pm 3 & \pm 704 \\
\hline \pm 4 & 1 & \pm 4 & \pm 600 \\
\hline \pm 5 & 1 & \pm 5 & \pm 500 \\
\hline \pm 6 & 1 & \pm 6 & \pm 420 \\
\hline \pm 7 & 1 & \pm 7 & \pm 380 \\
\hline \pm 8 & 1 & \pm 8 & \pm 340 \\
\hline \pm 9 & 1 & \pm 9 & \pm 320 \\
\hline \pm 10 & 1 & \pm 10 & \pm 288 \\
\hline \pm 11 & 1 & - & \pm 200 \\
\hline \pm 12 & 1 & - & \pm 136 \\
\hline \pm 13 & 1 & - & \pm 92 \\
\hline
\end{tabular}

Tabel 3 menunjukkan hasil pengujian pengukuran output modul receiver pada jalur data analog melalui jala-jala listrik. Terlihat bahwa sinyal analog dapat diterima dengan baik, hal itu terbukti dari hasil demodulasi yang menunjukan frekuensi input pada transmitter sama dengan frekuensi output pada receiver.

Setelah frekuensi lebih besar dari $4 \mathrm{kHz}$ tegangan keluaran terus menurun, karena adanya LPF yang digunakan dengan frekuensi penggal sekitar $4 \mathrm{kHz}$ (sudah cukup untuk melewatkan frekuensi wicara (voice) yang rentangnya sekitar $3 \mathrm{kHz}$.

\subsection{Pengujian Modem PLC Untuk Komunikasi Data Digital}

Pengujian ini dilakukan untuk mengetahui kinerja komunikasi data digital yang akan dikirimkan dari master ke slave melalui jala-jala listrik PLN. Pengujian ini dilakukan dengan kriteria sebagai berikut:

a. Komunikasi antara modul master dan slave melalui jala-jala listrik. 
b. Jaringan listrik yang digunakan adalah laboratorium skripsi FTEK UKSW.

c. Jalur komunikasi jala-jala listrik PLN menggunakan kabel sepanjang \pm 30 meter.

d. Komunikasi modul master dan slave menggunakan protokol USART yang sudah tersedia pada mikrokontroler dengan kecepatan 600 bps.

e. Modul master dikondisikan sebagai transmitter dan modul slave dikondisikan sebagai receiver.

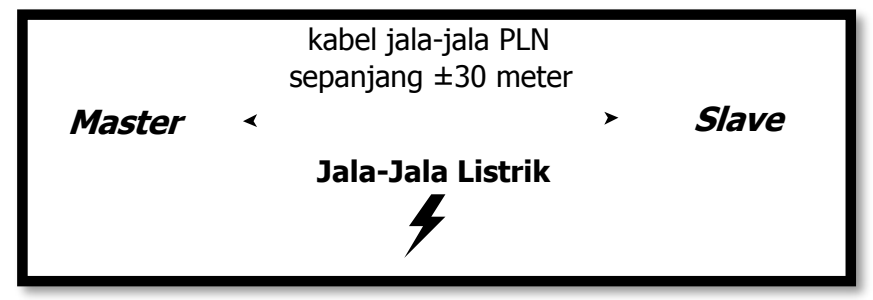

Gambar 13. Skema pengujian komunikasi data digital lewat jala-jala PLN

Langkah pengujiannya adalah dengan mengirimkan beberapa data serial dari master ke slave dengan panjang data yang berbeda-beda. Data serial yang dikirim berupa karakter. Tiap pengiriman data akan dilakukan sebanyak 100 kali dan mode modem selalu berada pada mode transmitter. Dilakukan juga pengujian dengan jeda, artinya ketika mengirimkan mode modem adalah transmitter kemudian setelah selesai mengirim mode diubah kembali menjadi receiver selama $500 \mathrm{~ms}$, kemudian saat hendak mengirim diubah lagi menjadi mode transmitter.

Tabel 4. Hasil Pengujian pengiriman data digital lewat jala-jala listrik PLN

\begin{tabular}{|c|c|}
\hline Data Serial & Keberhasilan $(\%)$ \\
\hline abcde & $100 / 100=100$ \\
\hline abcdABCDE & $100 / 100=100$ \\
\hline abcdABCDE12345 & $100 / 100=100$ \\
\hline abcdABCDE12345!@\#\$\% & $100 / 100=100$ \\
\hline
\end{tabular}

Dapat dilihat dari Tabel 4 dan Gambar 14 bahwa pengiriman data digital melalui jala-jala listrik dapat berjalan dengan sangat baik. Panjang data yang dikirim dalam pengujian ini sampai 25 karakter dalam sekali pengiriman secara kontinyu. Nantinya pada protokol yang digunakan pada sistem data paling panjang hanya 9 byte, setara dengan 9 karakter per pengiriman. Jadi diharapkan data akan sampai dengan baik dari master ke slave. 


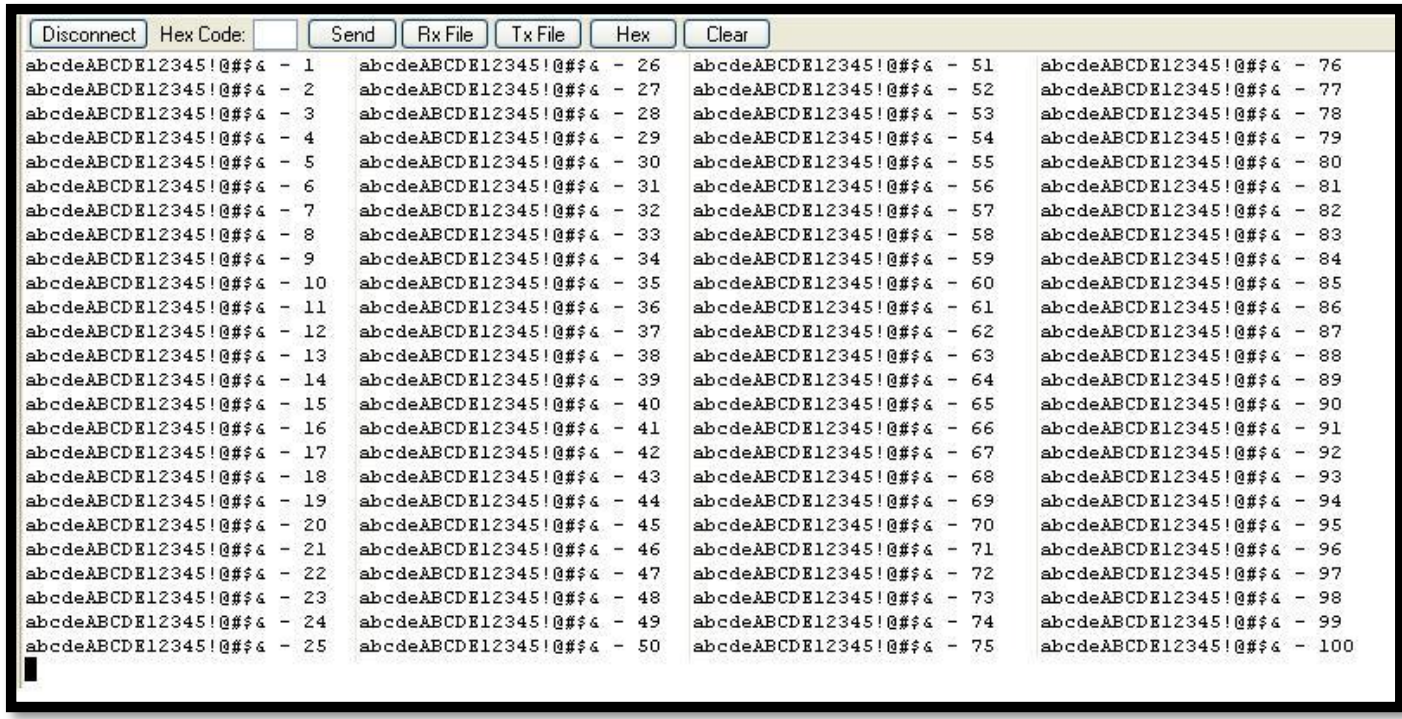

Gambar 14. Hasil pembacaan data serial di pin 18 modem PLC slave

\subsection{Pengujian Keseluruhan Sistem}

Pengujian ini dilakukan untuk mengetahui kinerja sistem kendali speaker yang dirancang ketika dijalankan pada sebuah jaringan listrik AC 220V. Pengujian yang dilakukan adalah pengiriman tiga macam perintah oleh modul master ke slave, yaitu perintah yang membutuhkan informasi balik dari slave, perintah yang membutuhkan konfirmasi slave ketika sudah melakukan tugasnya, dan perintah yang tidak memerlukan informasi/konfirmasi balik dari slave. Pengujian selanjutnya adalah pengiriman data analog berupa suara dari modul master ke modul slave. Semua pengujian dilakukan dengan kriteria pengujian sebagai berikut:

a. Seluruh modul dirangkai pada jaringan listrik satu fasa AC 220V.

b. Jarak antara modul master dan slave adalah \pm 75 meter.

c. Jaringan listrik yang digunakan pada pengujian adalah lab skripsi FTEK UKSW.

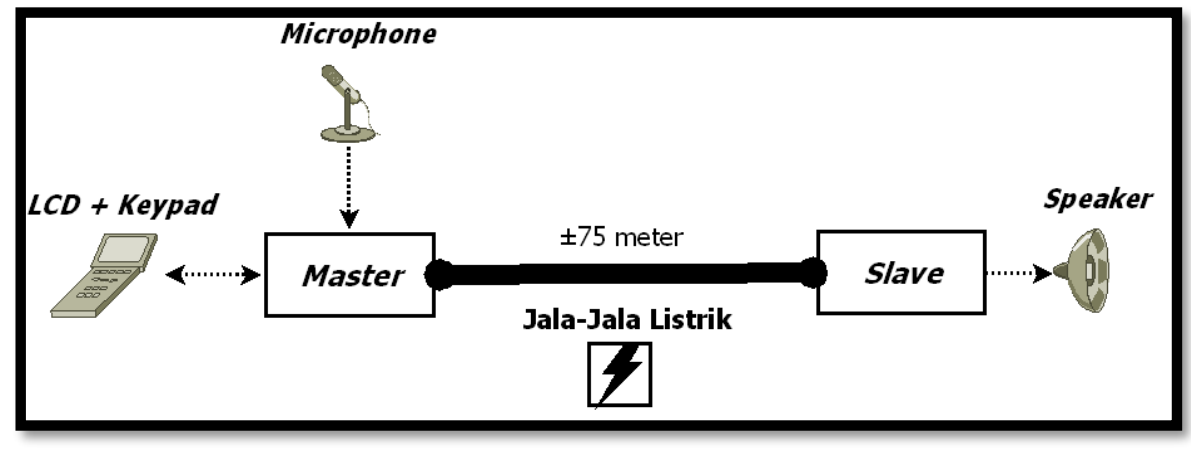

Gambar 15. Blok diagram pengujian keseluruhan sistem

Pada perancangan ini sebuah master dapat mengendalikan sampai 16 slave. Tetapi pada makalah ini hanya dicoba untuk enam buah penyuara $(1 \mathrm{~A}, 1 \mathrm{~B}, 2 \mathrm{~A}, 2 \mathrm{~B}, 3 \mathrm{~A}, 3 \mathrm{C})$ saja. Proses pengiriman datamenjamin tidak akan terjadi tumbukan karena pengiriman data yang memerlukan jawaban balik dari slave selalu dilakukan secara bergantian antara sebuah modul master dan sebuah modul slave. Pada perancangan software juga terdapat mekanisme pengulangan perintah sebanyak dua kali bila dalam selang beberapa waktu 
slave tidak memberikan jawaban balik untuk sebuah perintah yang memerlukan jawaban. Jika memang tidak ada jawaban setelah pengiriman perintah, maka diasumsikan bahwa slave yang dituju mengalami error.

Dari hasil pengujian dengan 20 kali percobaan, didapatkan perintah yang diberikan master dapat diterima dengan baik oleh slave. Slave dapat melakukan perintah setting dengan baik dan memberikan informasi/konfirmasi balik yang juga diterima master dengan baik.

Pengujian pengiriman data analog berupa suara juga dilakukan dengan kriteria yang sama. Hasilnya data analog yang dikirimkan dari master dapat diterima dengan cukup baik oleh slave tertentu yang dipilih dandisuarakan oleh penyuaranya. Suara dapat terdengar cukup jelas. Namun demikian nilai THD (Total Harmonic Distortion) dari keluaran amplifier masih cukup besar, yaitu sekitar 20\% sampai frekuensi $1 \mathrm{kHz}$ dan meningkat menjadi $25 \%$ dalam rentang frekuensi wicara (voice), sekitar $3 \mathrm{kHz}$. Setelah itu nilai THD makin besar seperti ditunjukkan Gambar 15.

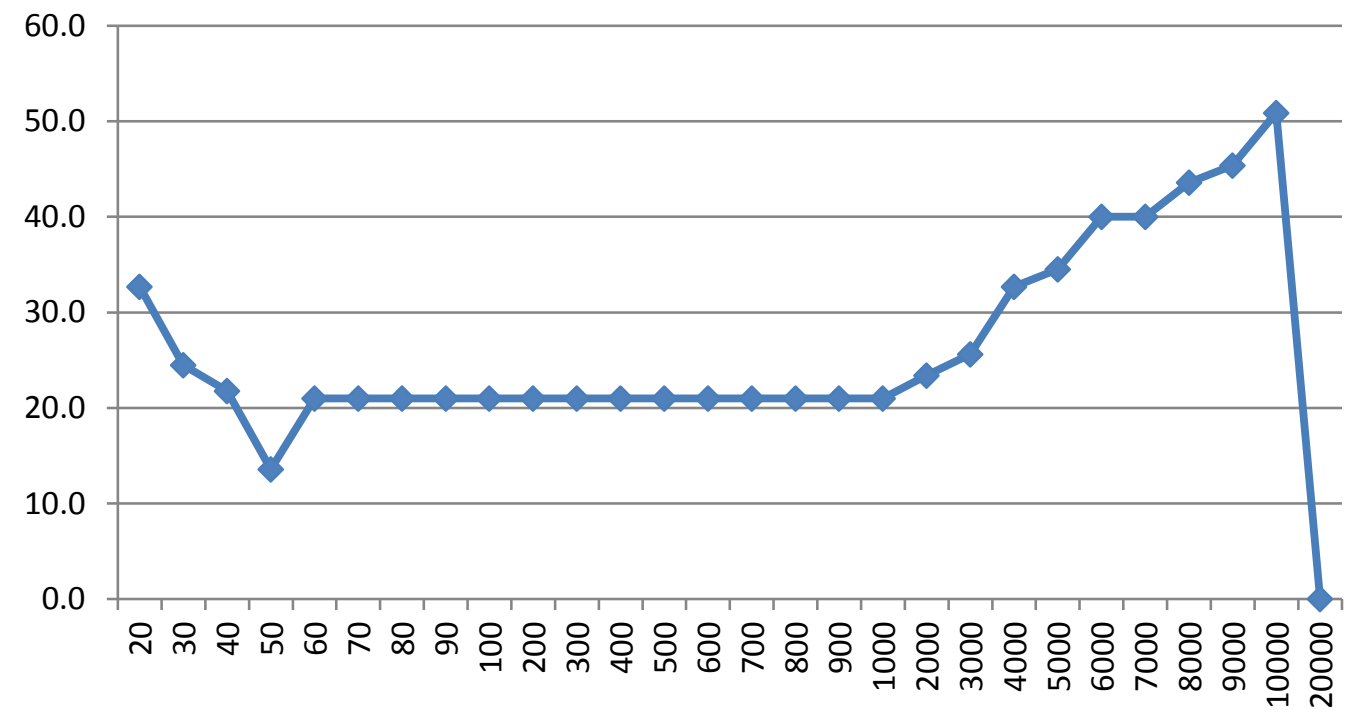

Gambar 16. Grafik THD outputamplifier (\%) terhadap frekuensi (Hz)

\section{Kesimpulan}

1. Sistem kendali speaker dengan metode komunikasi PLC berhasil diaplikasikan pada jala-jala listrik PLN 220 VAC satu fasa dengan jarak 75m.

2. Terdapat sebuah modul master yang dapat mengontrol enam modul slave (enam penyuara) dan menentukan penyuara pada slave mana yang akan aktif menyuarakan wicara yang dikirim dari modul master.

3. Data analog (wicara) yang sampai ke slave dapat terdengar jelas namun masih memiliki THD yang cukup besar, salah satu penyebabnya adalah adanya derau pada jala-jala. 


\section{Daftar Pustaka}

[1] Marzuki, Fahrul, Aplikasi Power Line Carrier (PLC) untuk Komunikasi pada Daerah Pedalaman, Konferensi dan Temu Nasional Teknologi Informasi dan Komunikasi untuk Indonesia, Jakarta, 21-23 Mei 2008.

[2] Kuntarto, GP, Teknologi Power Line Communications (PLC) Berkaitan dengan Aspek Teknik dan Ekonomi, Jurnal ULTIMATICS, Vol. 1 No. 1, Desember 2009.

[3] LM1893 LM2893 Carrier-Current Transceiver, Texas Instruments. [Online] http://www.ti.com/lit/ds/symlink/lm1893.pdf (diakses 1 April 2017)

[4] Sudaryanto, R, Pengiriman Data Pengendali Beban Listrik Jinjingan Memakai PLC (Power Line Carrier) Berbasis Mikrokontroler AT89C51, Jurnal INKOM, Vol. 1, No. 2, 2007.

[5] Arihutomo M, dkk, Sistem Monitoring Arus Listrik JalaJalaMenggunakan Power Line Carrier, Jurnal Teknik POMITS, Vol. 1, No. 1, 2012.

[6] Vinsensius Rahmat SP, dkk, Sistem Pengendali Peralatan Elektronik Serta Pemantauan Suhu Ruangan Berbasis Mikrokontroler dengan Media Komunikasi JalaJala, Jurnal Techne, Vol. 13, No. 1, April 2014. 
